\title{
Frequency Analysis for One day to Six Consecutive Days of Annual Maximum Rainfall for Mulde, Dist: Sindhudurg
}

\author{
S.S. Idate*, D.M. Mahale, H.N. Bhange and K.D. Gharde \\ Department of Soil and Water Conservation Engineering, \\ CAET, DBSKKV, Dapoli, Dist. Ratanagiri, Maharashtra, India \\ *Corresponding author
}

\section{Keywords}

Annual maximum rainfall, Probability Distribution functions, Frequency analysis

Article Info

Accepted:

22 January 2019

Available Online:

10 February 2019

\section{A B S T R A C T}

The primary need of water resource development in any area depends on estimation of rainfall at different probabilities for efficient planning and design of irrigation and drainage systems, command area development, soil and water conservation programmes and the optimum utilization of water resources in various agricultural production systems. The annual maximum daily rainfall data of 18 years (1991 to 2008) was obtained from ARS, Mulde. It was analyzed for maximum one day and extended days (up to 6 day) rainfall for Mulde. Normal, Log Normal, Gumbel, Pearson Type-III and Log Pearson Type-III were used for extreme rainfall events. The relationships between annual maximum values of 1 day and $\mathrm{D}$-days rainfall were found polynomial for Mulde $\left(\mathrm{R}^{2}=\right.$ 0.9292 to 0.9615 ). Based on statistical test for goodness of fit, the Pearson Type-III distribution was found as the best fit for observed 2-day, 5-day and 6-day annual maximum rainfall. Log Normal distribution gives the best for the annual maximum one day and 3-day annual maximum rainfall data whereas, normal distribution gives the best for the annual maximum 4-day annual maximum rainfall data for Mulde. Maximum value of 1-day rainfall for Mulde ranges from 102.8 to $295.0 \mathrm{~mm}$. Maximum value of 2-day rainfall ranges from 185.0 to $371.3 \mathrm{~mm}$. Maximum value of 3-day rainfall ranges from 260.2 to $463.8 \mathrm{~mm}$. Maximum value of 4-day rainfall ranges from 270.7 to $523.5 \mathrm{~mm}$. Maximum value of 5-day rainfall ranges from 295.2 to $643.3 \mathrm{~mm}$. Maximum value of 6day rainfall ranges from 358.4 to $676.3 \mathrm{~mm}$. An annual maximum rainfall of $167.03 \mathrm{~mm}$ in one day, $261.79 \mathrm{~mm}$ in two days, $335.24 \mathrm{~mm}$ in three days, $390.42 \mathrm{~mm}$ in four days, $450.22 \mathrm{~mm}$ in five days and 505.17 in six days was expected to occur at every two years. For recurrence interval of 100 years, the annual maximum rainfall expected in one day, two days, three days, four days, five days and six days was $368.31 \mathrm{~mm}, 487.73 \mathrm{~mm}$, $588.90 \mathrm{~mm}, 700.17 \mathrm{~mm}, 835.89 \mathrm{~mm}$ and $1068.35 \mathrm{~mm}$, respectively. Consecutive day's rainfall analysis provides valuable information for planning and management of runoff in watershed. 


\section{Introduction}

Most of the hydrological events occurring as natural phenomenon are observed only once. One of the important problems in hydrology deals with interpreting past records of hydrological events in terms of future probabilities of occurrence. The procedure for estimating frequency of occurrence of a hydrological event is known as frequency analysis.

Analysis of consecutive days annual maximum rainfall of different return period is a basic tool for safe and economical planning and design of structural and non-structural measures, small and medium hydraulic structures such as dams, bridges, culverts, spillways check dams, ponds, irrigation and drainage works in watershed management and command area development programme. Probability analysis can be used for prediction of occurrence of future events from available records of rainfall (Kumar and Kumar, 1989). Based on theoretical probability distributions, it would be possible to forecast the rainfall of various magnitudes with different return periods. Several distributions have been used for hydrological analysis as given by Chow (1951) and Youjivich (1972).

Several attempts have been made at different places for frequency analysis of annual maximum daily rainfall (Agarwal et al., 1988; Ajay Kumar et al., 2007; Dabral and Pandye 2008; Jeevarathnam and Jayakumar 1979; Patle, 2008; Sethy et al., 2005). Mulde comes under heavy rainfall zone having average annual rainfall $3128 \mathrm{~mm}$ still there is a scarcity of water from the month of March onwards.

This is due to undulating topography of the area steep slope more than $15 \%$. The hilly track is characterized by lateritic and hard rock. The soil texture in most of the part of the study area is loam to sandy loam with reddish brown colour. Rill erosion is very severe and has resulted in formation of gullies. Construction of rainwater harvesting structures, nala bund, embankment and masonry check dam is an important activity carried out in this area. This activity is presently done without ascertaining the amount of rainfall and corresponding expected runoff for the desired return period. Due to this fact, many of the soil conservation structures, constructed with huge investment and labour are failing occasionally due to flash floods. However analysis of rainfall data for computation expected rainfall for the desire frequency and consequent excess rainfall is required for safe design of any structure. The knowledge of consecutive days maximum rainfall can lead to successful crop planning. For prediction of design rainfall fairly accurately, various probability distribution functions are used. This study is an attempt to identify best theoretical frequency distribution out of the five based on Chi-square test of goodness of fit.

\section{Materials and Methods}

The daily rainfall data were collected from the meteorological observatory of Agriculture Research Station, Mulde (MS) located at an altitude of $17 \mathrm{~m}$ above mean sea level with $73^{\circ} 2^{\prime} \mathrm{E}$ longitude and $16^{\circ} 42^{\prime} \mathrm{N}$ latitude. The annual maximum daily rainfall data of 18 years (1991 to 2008) were analyzed.

The daily data, in a particular year, is converted to 2 to 6 days consecutive rainfall by summing up the rainfall of corresponding days. The annual maximum amount of 1-day to 6-days consecutive rainfall for each year was then taken for analysis.

The probability values were obtained by using Weibull formula (Chow 1964). The expected values of maximum rainfall were calculated 
by five well known probability distributions, viz., Normal, Log Normal, Gumbel, Pearson Type-III and Log Pearson Type-III distribution at different selected probabilities ie. 99, 95, 80, 50, 20, 5 and 1 per cent levels. Among these five distributions, the best fit distribution decided by Chi-square test for goodness of fit to observed values by the following equation

$C=\sum \frac{(O-E)^{2}}{E} \ldots(1)$

Where, $\mathrm{O}$ is the observed value and and $\mathrm{E}$ is the estimated values. The best probability function was determined by comparing Chisquare values obtained from each distribution and selecting the function that gives smallest chi-square value.

\section{Results and Discussion}

Extended day duration rainfall for 2, 3, 4, 5 and 6 days for Mulde was computed from the daily rainfall given in Table 1. Maximum value of 1-day rainfall for Mulde ranges from 102.8 to $295.0 \mathrm{~mm}$. Maximum value of 2-day rainfall ranges from 185.0 to $371.3 \mathrm{~mm}$. Maximum value of 3-day rainfall ranges from 260.2 to $463.8 \mathrm{~mm}$. Maximum value of 4-day rainfall ranges from 270.7 to $523.5 \mathrm{~mm}$. Maximum value of 5-day rainfall ranges from 295.2 to $643.3 \mathrm{~mm}$. Maximum value of 6-day rainfall ranges from 358.4 to $676.3 \mathrm{~mm}$.

\section{Relationship between annual maximum values of 1-day and D-days rainfall for Mulde}

The relationships were established by using the observed 1-day annual maximum rainfall and computed D-days annual maximum rainfall for same return period. All the relationships were found polynomial in nature with $R^{2}$ values ranging from 0.93 to 0.96 . The relationships are shown in Table 2.

\section{Probability analysis of annual} maximum 1-day and D-days rainfall

\section{Normal distribution}

The parameters mean $(\bar{x})$ and standard deviation $\left(\sigma_{\mathrm{x}}\right)$ of transformed 1-day rainfall are 178.43 and 47.11, respectively. The theoretical values of 1 day to 6-day annual maximum rainfall for different return periods are obtained using Normal distribution and they are presented in Table 3.

\section{Log normal distribution}

The statistical parameters such as mean $(\bar{x})$, standard deviation $\left(\sigma_{\mathrm{x}}\right)$ coefficient of variation and coefficient of skewness were computed for transformed data for 1-day and D-days rainfall. They are as 5.15, 0.26, 0.26 and 0.82 , respectively. The theoretical values of 1 day and D-days annual maximum rainfall for different return periods are obtained using Log Normal distribution presented in Table 4.

\section{Gumbel distribution}

The mean and standard deviation of original data for 1-day annual maximum rainfall are 178.43 and 47.11 respectively. The theoretical values of 1-day to D-days maximum rainfall for different return periods are obtained using Gumbel distribution presented in Table 5.

\section{Pearson type III distribution}

The parameters viz mean, standard deviation and coefficient of skewness of transformed 1day and D-days rainfall data were determined as $178.43,47.11$ and 0.81 , respectively. The frequency factor, $\mathrm{K}_{\mathrm{T}}$, values were determined for different return periods corresponding to the value of coefficient of skewness. The theoretical values of annual maximum 1-day to D-days rainfall for different return periods are obtained using Pearson Type- III distribution and presented in Table 6. 
Table.1 One day and extended days rainfall $(\mathrm{mm})$ for different return periods

\begin{tabular}{|c|c|c|c|c|c|c|}
\hline $\begin{array}{l}\text { Return } \\
\text { period } \\
\text { (Years) }\end{array}$ & 1-D & 2-D & 3-D & 4-D & 5-D & 6-D \\
\hline 19.00 & 295.0 & 371.3 & 463.8 & 523.5 & 643.3 & 676.3 \\
\hline 9.50 & 257.6 & 351.2 & 457.8 & 505.5 & 601.7 & 657.2 \\
\hline 6.33 & 218.0 & 320.0 & 421.0 & 505.0 & 588.5 & 652.8 \\
\hline 4.75 & 210.0 & 319.8 & 417.0 & 496.8 & 587.4 & 643.4 \\
\hline 3.80 & 198.6 & 318.4 & 415.2 & 482.8 & 544.8 & 625.8 \\
\hline 3.17 & 184.8 & 314.2 & 393.5 & 481.6 & 524.0 & 607.7 \\
\hline 2.71 & 183.5 & 307.0 & 373.4 & 448.3 & 489.5 & 586.6 \\
\hline 2.38 & 178.0 & 306.5 & 373.0 & 437.4 & 488.2 & 524.9 \\
\hline 2.11 & 172.6 & 297.6 & 360.3 & 401.0 & 469.8 & 524.6 \\
\hline 1.90 & 172.0 & 260.6 & 324.4 & 381.6 & 463.5 & 501.7 \\
\hline 1.73 & 169.4 & 253.6 & 301.5 & 381.0 & 442.6 & 497.1 \\
\hline 1.58 & 167.5 & 244.5 & 300.2 & 355.0 & 423.4 & 483.1 \\
\hline 1.46 & 157.7 & 229.8 & 299.9 & 346.8 & 400.9 & 475.4 \\
\hline 1.36 & 154.0 & 226.1 & 298.6 & 342.3 & 394.3 & 458.3 \\
\hline 1.27 & 153.2 & 223.0 & 275.2 & 324.3 & 390.4 & 438.2 \\
\hline 1.19 & 119.2 & 200.0 & 267.7 & 316.2 & 370.7 & 426.7 \\
\hline 1.12 & 117.8 & 192.8 & 264.4 & 310.0 & 343.0 & 364.0 \\
\hline 1.06 & 102.8 & 185.0 & 260.2 & 270.7 & 295.2 & 358.4 \\
\hline
\end{tabular}

Table.2 Relationship between 1-day and D-days annual maximum rainfall

\begin{tabular}{|c|l|c|}
\hline D days & \multicolumn{1}{|c|}{ Relationship } & $\mathbf{R}^{2}$ \\
\hline 2 & $Y=1 E-06 x^{4}-0.0011 x^{3}+0.3344 x^{2}-40.297 x+1882.7$ & 0.94 \\
\hline 3 & $Y=1 E-06 x^{4}-0.0012 x^{3}+0.3645 x^{2}-46.662 x+2332.9$ & 0.94 \\
\hline 4 & $Y=2 E-06 x^{4}-0.0015 x^{3}+0.4654 x^{2}-57.745 x+2780$ & 0.93 \\
\hline 5 & $Y=1 E-06 x^{4}-0.0011 x^{3}+0.3302 x^{2}-40.42 x+2016.6$ & 0.96 \\
\hline 6 & $Y=2 E-06 x^{4}-0.0016 x^{3}+0.4935 x^{2}-60.676 x+2953.8$ & 0.95 \\
\hline
\end{tabular}

$\mathrm{x}=$ One day maximum rainfall, $\mathrm{mm}(102.8<\mathrm{x}<295.0) ; \mathrm{Y}=$ Extended day maximum rainfall, $\mathrm{mm}$ 
Table.3 Theoretical values of 1-day to extended days rainfall $(\mathrm{mm})$ using Normal distribution

\begin{tabular}{|c|c|c|c|c|c|c|c|}
\hline $\begin{array}{c}\text { Sr. } \\
\text { No }\end{array}$ & $\begin{array}{c}\text { Return } \\
\text { period } \\
\text { (Years) }\end{array}$ & 1-D & 2-D & 3-D & 4-D & 5-D & 6-D \\
\hline 1 & 1.0101 & 68.80 & 141.99 & 188.79 & 219.09 & 243.79 & 293.71 \\
\hline 2 & 1.0526 & 100.91 & 180.49 & 235.48 & 273.87 & 310.07 & 362.31 \\
\hline 3 & 1.25 & 138.78 & 225.89 & 290.53 & 338.47 & 388.24 & 443.21 \\
\hline 4 & 2 & 178.43 & 273.41 & 348.17 & 406.10 & 470.07 & 527.90 \\
\hline 5 & 5 & 218.07 & 320.94 & 405.81 & 473.73 & 551.90 & 612.59 \\
\hline 6 & 20 & 255.94 & 366.33 & 460.87 & 538.33 & 630.06 & 693.49 \\
\hline 7 & 100 & 288.05 & 404.83 & 507.56 & 593.11 & 696.34 & 762.09 \\
\hline
\end{tabular}

Table.4 Theoretical values of 1-day to extended days rainfall (mm) using Log Normal distribution

\begin{tabular}{|c|c|c|c|c|c|c|c|}
\hline $\begin{array}{c}\text { Sr. } \\
\text { No }\end{array}$ & $\begin{array}{c}\text { Return } \\
\text { period } \\
\text { (Years) }\end{array}$ & 1-D & 2-D & 3-D & 4-D & 5-D & 6-D \\
\hline 1 & 1.0101 & 108.59 & 179.46 & 234.99 & 270.47 & 308.89 & 314.99 \\
\hline 2 & 1.0526 & 119.91 & 196.88 & 256.69 & 296.31 & 339.13 & 354.24 \\
\hline 3 & 1.25 & 138.78 & 223.30 & 289.34 & 335.33 & 384.37 & 415.37 \\
\hline 4 & 2 & 167.03 & 261.79 & 335.24 & 390.42 & 450.22 & 505.17 \\
\hline 5 & 5 & 211.26 & 316.22 & 399.24 & 467.65 & 543.84 & 637.24 \\
\hline 6 & 20 & 277.85 & 393.14 & 485.84 & 572.80 & 674.59 & 827.26 \\
\hline 7 & 100 & 368.31 & 487.73 & 588.90 & 700.17 & 835.89 & 1068.35 \\
\hline
\end{tabular}

Table.5 Theoretical values of 1-day to extended days rainfall ( $\mathrm{mm}$ ) using Gumbel distribution

\begin{tabular}{|c|c|c|c|c|c|c|c|}
\hline $\begin{array}{c}\text { Sr. } \\
\text { No }\end{array}$ & $\begin{array}{c}\text { Return } \\
\text { period } \\
\text { (Years) }\end{array}$ & 1-D & 2-D & 3-D & 4-D & 5-D & 6-D \\
\hline 1 & 1.0101 & 101.12 & 180.74 & 235.78 & 274.23 & 310.50 & 362.75 \\
\hline 2 & 2 & 170.68 & 264.14 & 336.93 & 392.90 & 454.10 & 511.37 \\
\hline 3 & 5 & 212.32 & 314.05 & 397.46 & 463.93 & 540.04 & 600.32 \\
\hline 4 & 10 & 239.88 & 347.09 & 437.53 & 510.94 & 596.93 & 659.20 \\
\hline 5 & 25 & 274.75 & 388.90 & 488.23 & 570.43 & 668.91 & 733.70 \\
\hline 6 & 50 & 301.01 & 420.37 & 526.41 & 615.22 & 723.11 & 789.80 \\
\hline 7 & 100 & 326.20 & 450.57 & 563.03 & 658.19 & 775.10 & 843.60 \\
\hline
\end{tabular}


Table.6 Theoretical values of 1-day to extended days rainfall (mm) using Pearson type III distribution

\begin{tabular}{|c|c|c|c|c|c|c|c|}
\hline $\begin{array}{c}\text { Sr. } \\
\text { No }\end{array}$ & $\begin{array}{c}\text { Return } \\
\text { period } \\
\text { (Years) }\end{array}$ & 1-D & 2-D & 3-D & 4-D & 5-D & 6-D \\
\hline 1 & 1.0101 & 96.66 & 140.40 & 202.99 & 219.28 & 251.88 & 288.51 \\
\hline 2 & 2 & 113.07 & 179.88 & 241.21 & 273.95 & 313.26 & 360.32 \\
\hline 3 & 5 & 138.22 & 225.99 & 289.82 & 338.46 & 387.75 & 443.57 \\
\hline 4 & 10 & 172.20 & 273.77 & 344.97 & 406.06 & 468.24 & 529.08 \\
\hline 5 & 25 & 215.00 & 321.04 & 404.65 & 473.72 & 551.31 & 612.92 \\
\hline 6 & 50 & 265.06 & 365.71 & 466.06 & 538.40 & 633.12 & 691.46 \\
\hline 7 & 100 & 315.20 & 403.23 & 521.62 & 593.29 & 704.41 & 756.89 \\
\hline
\end{tabular}

Table.7 Theoretical values of 1-day to extended days rainfall (mm) using Log Pearson type III distribution

\begin{tabular}{|c|c|c|c|c|c|c|c|}
\hline $\begin{array}{c}\text { Sr. } \\
\text { No }\end{array}$ & $\begin{array}{c}\text { Return } \\
\text { period } \\
\text { (Years) }\end{array}$ & 1-D & 2-D & 3-D & 4-D & 5-D & 6-D \\
\hline 1 & 1.0101 & 93.54 & 154.53 & 219.28 & 237.68 & 266.69 & 310.46 \\
\hline 2 & 2 & 173.38 & 271.02 & 341.19 & 402.72 & 465.59 & 524.81 \\
\hline 3 & 5 & 215.27 & 321.37 & 402.72 & 473.15 & 552.08 & 613.76 \\
\hline 4 & 10 & 240.43 & 348.33 & 440.55 & 512.86 & 598.41 & 660.69 \\
\hline 5 & 25 & 271.64 & 378.44 & 485.29 & 555.9 & 650.13 & 712.85 \\
\hline 6 & 50 & 293.76 & 398.11 & 516.42 & 583.45 & 683.91 & 751.62 \\
\hline 7 & 100 & 314.05 & 415.91 & 547.02 & 609.54 & 714.50 & 783.42 \\
\hline
\end{tabular}

Table.8 Chi-square test of goodness of fit for probability distributions for annual maximum 1-D to 6-D rainfall of Mulde for different distributions.

\begin{tabular}{|c|c|c|c|c|c|c|}
\hline Sr. No & $\begin{array}{c}\text { Consecutive } \\
\text { days }\end{array}$ & $\begin{array}{c}\text { Normal } \\
\text { Distribution }\end{array}$ & $\begin{array}{c}\text { Log } \\
\text { Normal } \\
\text { Distribution }\end{array}$ & $\begin{array}{c}\text { Gumbel } \\
\text { Distribution }\end{array}$ & $\begin{array}{c}\text { Learson Type III } \\
\text { Distribution }\end{array}$ & $\begin{array}{c}\text { Poarson } \\
\text { Type III } \\
\text { Distribution }\end{array}$ \\
\hline $\mathbf{1}$ & 1- D & 10.3 & $\mathbf{6 . 8}$ & 9.0 & 8.0 & $\mathbf{8 . 6}$ \\
\hline $\mathbf{2}$ & 2- D & 6.4 & 7.0 & 11.9 & $\mathbf{6 . 3}$ & $\mathbf{8 . 3}$ \\
\hline $\mathbf{3}$ & 3- D & 3.6 & $\mathbf{3 . 2}$ & 7.0 & 3.7 & $\mathbf{7 . 5}$ \\
\hline $\mathbf{4}$ & 4- D & $\mathbf{4 . 0 7}$ & 8.7 & 8.2 & 4.09 & $\mathbf{1 7 . 5}$ \\
\hline $\mathbf{5}$ & 5- D & 4.7 & 6.8 & 7.9 & $\mathbf{4 . 5}$ & $\mathbf{2 1 . 1}$ \\
\hline $\mathbf{6}$ & 6- D & $\mathbf{7 . 0 5}$ & $\mathbf{1 5 . 5}$ & $\mathbf{1 3 . 1}$ & $\mathbf{6 . 9 6}$ & $\mathbf{2 0 . 4}$ \\
\hline
\end{tabular}




\section{Log Pearson type III distribution}

The parameters like mean, standard deviation and coefficient of skewness of transformed data for 1-day and D-days rainfall were determined as $2.238,0.113$ and -0.044 respectively.

The theoretical values of annual maximum 1day to D-days rainfall for different return periods are obtained using Log Pearson TypeIII distribution and presented given in Table 7.

\section{Test for goodness of fit}

The observed and expected values of rainfall were statistically compared for their goodness of fit using Chi-square test. The Chi-square values for various return periods were calculated and are presented in Table 8 .

The Pearson Type-III distribution was found as the best fit for observed 2-day, 5-day and 6-day annual maximum rainfall. Log Normal distribution gives the best for the annual maximum one day and 3-day annual maximum rainfall data whereas; Normal distribution gives the best for the annual maximum 4-day annual maximum rainfall data. An annual maximum rainfall of $167.03 \mathrm{~mm}$ in one day, $261.79 \mathrm{~mm}$ in two days, $335.24 \mathrm{~mm}$ in three days, $390.42 \mathrm{~mm}$ in four days, $450.22 \mathrm{~mm}$ in five days and 505.17 in six days was expected to occur at every two years.

For recurrence interval of 100 years, the annual maximum rainfall expected in one day, two days, three days, four days, five days and six days was $368.31 \mathrm{~mm}, 487.73 \mathrm{~mm}, 588.90 \mathrm{~mm}$, $700.17 \mathrm{~mm}, 835.89 \mathrm{~mm}$ and $1068.35 \mathrm{~mm}$, respectively. Consecutive day's rainfall analysis provides valuable information for planning and management of runoff in watershed.

\section{References}

Agarwal, M.C., Katiyar, V.S. and Ram Babu. (1998). Probability analysis of annual maximum daily rainfall of U.P. Himalaya. Indian J. Soil Cons., 16 (1): 35-42

Ajay Kumar, K.K. Kaushal and R.D. Singh. (2007). Prediction of annual maximum daily rainfall of Almora based on probability analysis. Indian J. Soil Cons. 35(1): 82-83.

Chow, V. T. (1951). A general formual for hydrogeological frequency analysis. Trans. Am. Geophys. Union. Vol 32: 231-237.

Chow, V.T. (1964). Hand Book Applied Hydrology. Chapter 8, Section 1, Mc Graw Hill, New York.

Dabral, P.P., Pandey A. (2008). Frequency analysis for one day to seven consecutive days of annual maximum rainfall for the district of North Lakhimpur, Assam. IE (I) Journal- AG Vol 89: 29-34

Kumar D. and Kumar S. (1989). Rainfall distribution pattern using frequency analysis. J. Agric. Engg. ISAE, 26(1): 3338.

Jeevarathnam, K. and M. Jayakumar. (1979). Probability analysis of annual maximum daily rainfall for Ootacamund. Indian $J$. Soil Cons. 7(1): 10-16.

Patle G. T. (2008). Probability analysis of consecutive days annual maximum rainfall for the design of surface drains in semi-arid Maharashtra. Indian J. Soil Cons. 36(3): 144-147

Sethy, B.K., S. Ali and S.N. Prassad. (2005). Frequency analysis for one day to five consecutive days annual maximum rainfall for South Eastern Rajasthan. Indian J. Soil Cons. 33(1): 22-26.

Youjivich, V. (1972). Probability and statistic in hydrology. Water Recourses Publication Fout Collins, Colorado, USA.

\section{How to cite this article:}

Idate, S.S., D.M. Mahale, H.N. Bhange and Gharde, K.D. 2019. Frequency Analysis for One day to Six Consecutive Days of Annual Maximum Rainfall for Mulde, Dist: Sindhudurg. Int.J.Curr.Microbiol.App.Sci. 8(02): 3069-3075. doi: https://doi.org/10.20546/ijcmas.2019.802.359 